\title{
Identifikasi Tantangan Adopsi E-commerce Pada Rumah Produksi Seulanga
}

\author{
Juwita $^{\mathrm{a}^{*}}$, Nursanty Risa ${ }^{\mathrm{b}}$, Fahlevi Heru ${ }^{\mathrm{c}}$ \\ aProgram Studi Manajemen Informatika, Fakultas MIPA, Universitas Syiah Kuala \\ bJurusan Biologi, Fakultas MIPA, Universitas Syiah Kuala \\ cJurusan Akuntansi, Fakultas Ekonomi, Universitas Syiah Kuala
}

Naskah Diterima : 29 April 2017; Diterima Publikasi : 13 Mei 2017

DOI : 10.21456/vol7iss2pp104-113

\begin{abstract}
Peukan Bada is one of districts in Aceh Besar which directly opposite to Indian Ocean. This district had abundant marine fishery resources. In 2016 Seulanga home production has implemented E-commerce website to support their sales and promotion process, but after six months of releasing, there were no transcations occured. Fourth stage of E-commerce adoption in small and medium bussiness were achieved, if online transactions including ordering and payment have occured. To achieved that a reliable e-commerce website and organizational readiness was needed.The objective of this study was to identify the challenge of E-commerce adoption in Seulanga home production. It used Fishbone cause and effect with 4P approach (Price, Product, Place and Promotion). Data collecting using focus group discussion and site search testing technic. This research taken place in Peukan Bada district, Exactly in Lamteungoh village. This research had successfully identified causes that challenge the E-commerce adoption in seulanga home production, those were : product were unregistered, the fluctuative price, no managerial skilled staf and IT skilled staff, no promotion strategy applied and unsmart site search features. All those factors become barries of E-commerce adoption for seulanga home production, so Seulanga need external intervention to cope their continuity in bussiness.
\end{abstract}

Keywords: Fishbon; 4P Approach; E-commerce.

\begin{abstract}
Abstrak
Peukan Bada merupakan salah satu kecamatan di Aceh Besar yang berhadapan langsung dengan samudera hindia. Kecamatan ini memiliki sumber daya perikanan laut yang melimpah. Pada tahun 2016 rumah produksi Seulanga telah memiliki website E-commerce untuk mendukung promosi dan transaksi penjualan mereka, namun setelah enam bulan perilirisan, tidak ada satupun transaksi yang terjadi melalui website. Adopsi E-commerce pada usaha kecil menengah (UKM) mencapai tahap keempat apabila telah terjadinya transaksi online termasuk pemesanan dan pembayaran. Untuk mencapai tahap keempat adopsi E-commerce, diperlukan kesiapan, baik itu website E-commerce yang mumpuni maupun kesiapan organisasi. Penelitian ini bertujuan untuk mengidentifikasi hambatan- hambatan apa saja yang dihadapi oleh Seulanga dalam menerapkan E-commerce. Penelitian menggunakan diagram Fishbone sebab akibat dengan pendekatan 4P (Price, Product, Place dan Promotion). Pengumpulan data dilakukan dengan diskusi terpusat dan pengujian website E-commerce dengan menggunakan skenario pengujian site search. Penelitian dilaksanakan di Kecamatan Peukan Bada, tepatnya di desa Lamteungoh. Penelitian telah berhasil mengidentifikasi sebab-sebab hambatan dalam penerapan E-commerce di rumah produksi Seulanga, yaitu adalah: belum terdaftarnya produk, belum tetapnya harga produk, tidak adanya staff yang terampil dalam bidang manajerial dan bidang Teknologi Informasi (TI), tidak adanya strategi promosi tertentu, serta fitur site search yang masih belum bisa memenuhi seluruh kriteria pencarian yang handal.
\end{abstract}

Kata kunci: Fishbone; E-commerce; Pendekatan 4P

\section{Pendahuluan}

Provinsi Aceh terletak di wilayah barat Indonesia. Aceh memiliki garis pantai yang panjang yaitu 1.660 $\mathrm{Km}$, dengan luas keseluruhan lautan sebesar 295.370 $\mathrm{Km}^{2}$ yang terdiri dari $56.563 \mathrm{Km}^{2}$ lautan bebas dan $238.807 \mathrm{Km}^{2}$ zona ekonomi ekslusif (ZEE)

*) Penulis korespondensi: juwita_tk@yahoo.com
(Hamdani, 2011). Salah satu kabupaten yang ada di provinsi Aceh adalah Aceh Besar yang terletak pada posisi $5,2^{\circ}-5,8^{\circ} \mathrm{LU}$ dan $95,0^{\circ}-95,8^{\circ} \mathrm{BT}$, memiliki panjang pantai $195 \mathrm{Km}$, dan luas wilayah $2.974,12$ $\mathrm{Km}^{2}$. Daerah dataran dari kabupaten ini umumnya terdapat di wilayah pesisir timur dan utara serta pesisir barat. Kecamatan Peukan Bada salah satu 
kecamatan yang ada di Kabupaten Aceh Besar yang berhadapan langsung dengan Samudera Hindia. Kecamatan ini memiliki potensi sumber daya perikanan laut yang melimpah. Populasi di kecamatan Peukan Bada mencapai 15.000 jiwa yang tersebar di 26 desa. Sebagian dari mereka bermata pencaharian sebagai nelayan (Pokja AMPL Aceh Besar, 2011).

Untuk meningkatkan pendapatan keluarga, sebagian kaum ibu di desa Lam Teungoh kecamatan Peukan Bada memberdayakan diri mereka. Mereka berinisiatif untuk mendirikan rumah produksi Seulanga di tahun 2008. Rumah produksi Seulanga mengolah ikan menjadi nugget dan bakso. Pada tahun-tahun awal beroperasi, produksi dan promosi dilakukan secara sederhana. Terbatasnya sumber daya manusia dan peralatan membuat produksi hanya dilakukan dalam skala kecil. Sedangkan promosi hanya dilakukan dari mulut ke mulut.

Seiring dengan berjalannya waktu, rumah produksi Seulanga terus memperbaiki cara menjalankan usahanya. Terlebih lagi beberapa pihak luar seperti Universitas Syiah Kuala, telah memberikan bantuan peralatan produksi dan pelatihan manajemen (Nursanty et al, 2015). Sehingga memungkinkan bagi Seulanga untuk meningkatkan kuantitas produksi. Dan sekarang tampaknya rumah produksi Seulanga telah siap untuk mengadopsi strategi perdagangan dan promosi baru.

Seulanga memilih E-commerce sebagai strategi penjualan dan pemasaran nya, para anggota rumah produksi Seulanga berharap melalui penjualan dan pemasaran online mereka dapat meningkatkan omset serta mengurangi waktu dan biaya promosi. Namun sayangnya setelah enam bulan implementasi website E-commerce, tidak ada satupun transaksi atau pemesanan yang datang dari website tersebut. Hal ini merupakan sinyalemen buruk, sehingga perlu dilakukan penelitian menyeluruh terhadap seluruh aspek yang terkait. Penelitian ini bertujuan untuk mengidentifikasi hambatan -hambatan yang dihadapi oleh rumah produksi Seulanga dalam mengadopsi E-commerce. Pengumpulan data dilakukan dengan teknik dikusi terfokus dan observasi website E-commerce. Metode analisis yang digunakan adalah Fishbone cause and effect dengan strategi bauran pemasaran atau dikenal juga sebagai pendekatan 4P (Price, Product, People dan Promotion).

\section{Kerangka Teoritis}

\subsection{Fishbone Analysis}

Analisis Fishbone biasanya disebut juga sebagai "Diagram Ishikawa" karena ditemukan oleh Mr. Kaoru Ishikawa, seorang statistik kendali kualitas yang berasal dari jepang. Diagram disebut Fishbone karena penampakannya mirip seperti tulang ikan. Analisis diagram Fishbone khusus digunakan untuk mengevaluasi penyebab dan sub-penyebab dari suatu masalah tertentu sehingga membantu untuk mengungkapkan seluruh gejala yang terjadi pada suatu usaha/bisnis. Sehingga hal tersebut menjadi alasan mengapa Fishbone juga disebut sebagai analisis sebab-akibat. Dalam susunan diagram Fishbone, masalah utama yang ingin diselesaikan diletakkan pada kepala diagram. Dan penyebabpenyebab utama disusun sebagai tulang-tulang. Tulang yang lebih kecil dibuat untuk mewakili subpenyebab. Analisis Fishbone merupakan tool untuk menganalisis proses bisnis dan efektivitasnya. Akhirnya setelah selesai, diagram akan memberikan gambaran evaluasi yang menyeluruh terhadap penyebab utama serta mengungkapkan akar masalah (Tarun, Kanti Bose, 2012).

Ada beberapa pendekatan yang bisa digunakan sebagai panduan untuk mengidentifikasi faktor utama dalam proses pembuatan diagram sebab-akibat (Poerwanto, 2016).

1. Pendekatan 4M (biasanya digunakan oleh perusahaan manufaktur). Dalam pendekatan ini faktor utama didefinisikan sebagai: Machine (equipment), Method (process/inspection), Material (raw, consumables).

2. Pendekatan 8P (umumnya digunakan untuk perusahaan jasa). Faktor utama adalah: People, Process, Policies, Procedures, Price, Promotion, Place/plant, Product.

3. Pendekatan 4S (umumnya digunakan untuk perusahaan jasa) faktor utama adalah: Surronding, Supplier, System and Skills.

4. Pendekatan 4P (pendekatan untuk manajemen pemasaran) pendekatan ini digunakan oleh manajemen pemasaran untuk memberikan pedoman terhadap beberapa faktor utama yaitu: Price, Product, Place and Promotion.

\subsection{E-commerce}

E-commerce (electronic commerce) merupakan proses pembelian, penjualan atau penukaran produk barang, jasa dan informasi melalui jaringan komputer (Siregar, 2010). E-commerce akan merubah semua kegiatan marketing dan juga sekaligus memangkas biaya-biaya operasional untuk kegiatan perdagangan (Vermaat, 2007). Penetrasi E-commerce telah menjangkau indonesia. Gambar 1. Statistik pembelian pada website E-commerce di Indonesia tahun 2015 menunjukan bahwa oxl.co.id menjadi website E-commerce yang sangat terkenal di Indonesia pada tahun 2015 yang mendapatkan $23,03 \%$ pembeli. Hal ini membuktikan bahwa penetrasi E-commerce telah masuk ke Indonesia. 


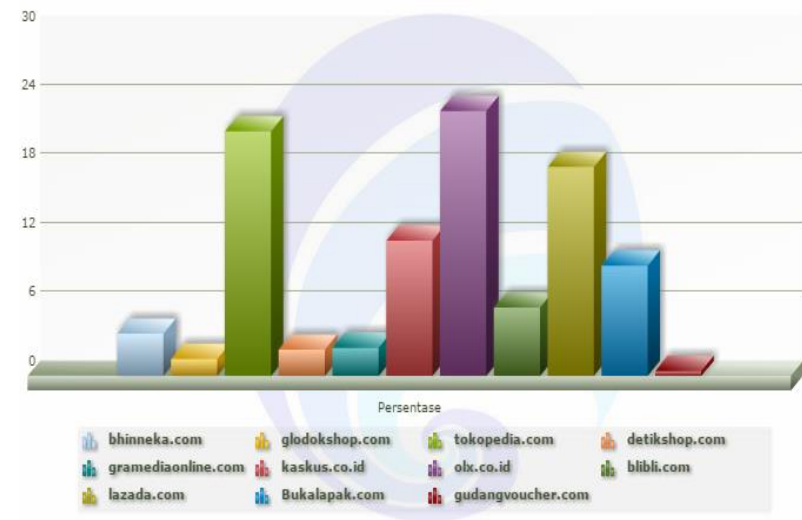

Gambar 1. Statistik pembelian pada website E-commerce di Indonesia tahun 2015, Sumber : Ditjen Aptika

\subsection{Pengujian Website E-commerce}

Setelah selesai dikembangkan, sebuah website Ecommerce sebaiknya tidak serta merta diluncurkan kepada konsumen, pengujian perlu dilakukan terlebih dahulu. Dalam siklus pengembangan aplikasi, baik itu berbasis desktop ataupun berbasis web penting dilakukannya pengujian. Tujuan akhir yang ingin dicapai dari proses pengujian adalah tersedianya aplikasi yang berkualitas dan bebas dari kesalahan (bug).

Secara umum pengujian aplikasi perlu dilakukan karena:

a. memberikan informasi yang dapat digunakan oleh programmer untuk mencegah bug pada perangkat lunak yang dikembangkan.

b. memberikan informasi yang dibutuhkan oleh pihak manajemen untuk menilai secara rasional risiko yang mungkin ditimbulkan akibat penggunaan suatu aplikasi.

c. dapat mencapai aplikasi yang bebas- bug seperti yang digaransikan

d. Menghasilkan rancangan yang dapat diuji, dimana rancangan yang telah teruji ini memiliki kelebihan mudah divalidasi, diperbanyak dan juga mudah diperlihara.

e. mendapatkan informasi mengenai hal hal apa saja yang dapat menyebabkan rusaknya aplikasi.

f. memvalidasi aplikasi atau dengan kata lain menunjukkan bagaimana kerja dari suatu aplikasi.

Berdasarkan rancangan tujuannya, jenis- jenis pengujian dapat dibedakan menjadi dirty test (pengujian negatif) yaitu: merupakan test yang dirancang untuk merusak aplikasi atau untuk menemukan bug aplikasi. Sedangkan clean test (pengujian positif) merupakan pengujian yang dirancang untuk menunjukan bahwa aplikasi telah bekerja dengan benar (Bazier, 1995).

Website E-commerce juga merupakan aplikasi web sehingga perlu dilakukan pengujian yang sesuai dengan kebutuhannya (Editor, 2017).

Sebelum melakukan pengujian, perlu disiapkan sebuah rencana pengujian (test plan). Wikipedia
(2017) mendefinisikan test plan sebagai sebuah dokumen yang merincikan tujuan dibuatnya aplikasi, target pasar, sumber daya manusia yang terlibat dalam pengujian, proses-proses yang dilalui dalam pengujian dan hasil pengujian.

Format dokumen test plan dapat bervariasi sesuai dengan jenis produk aplikasi dan organisasi yang ditinjau. Penelitian ini memilih pengujian site search. Pertimbangannya adalah bahwa site search merupakan bagian penting dari banyak website, terlebih lagi untuk website E-commerce yang mungkin memiliki ribuan produk dan katagori. Ada beberapa daftar pertanyaan yang dapat digunakan dalam rencana pengujian untuk site search antara lain:

1. Kemudahan menemukan site search pada website E-commerce. Dengan daftar checklist seperti berikut:

a. apakah search diletakkan di tempat yang mudah dijumpai?

b. apakah diletakkan di kanan atas pada setiap halaman website?

c. apakah desainnya membuat search gampang dijumpai?

d. apakah search memiliki kolom yang disediakan untuk menulis teks pencarian?

2. Eksekusi site search

a. apakah user bisa mencari dengan satu kata, atau dua kata dan mendapatkan hasil yang masuk akal?

b. apakah dapat mencari dengan kode produk?

c. apakah user mendapatkan pesan validasi bila melakukan inputan kosong?

3. Site search Suggestion

a. apakah site search memiliki fasilitas auto suggestion, yang akan tampil saat user mulai mengetikkan kata di kotak pencarian?

b. jika iya, apakah auto suggestion menampilkan suggestion yang relevan?

c. apa yang terjadi jika user mengklik pada salah satu suggestion, apakah hasil yang ditampilkan relevan?

4. Advanced search

a. apakah ada advance search?

b. bila ada, pilihan apa yang tersedia?

5. Urutan hasil site search

a. apakah hasil pencarian ditampilkan dalam urutan yang masuk akal?

b. apakah mungkin untuk melakukan pengururtan ulang terhadap hasil pencarian?

6. Tampilan hasil site search

a. Apakah hasil pencarian mudah dipahami dan jelas ditampilkan?

b. apakah judul halaman, dan halaman deskripsi ditampilkan?

c. apakah ada image yang dtampilkan dalam hasil pencarian? 
d. apakah mudah dipahami dimana untuk mengklik atau melihat produk?

e. apakah ada gambar yang dikembalikan dari hasil pencarian?

f. apakah ukuran gambar benar?

g. apakah gambar dapat di klik?

h. apakah dengan mengklik pada gambar membawa user ke halaman atau produk yang benar? (Batey, 2013).

\subsection{Hambatan dan tantangan Adopsi E-commerce}

Beberapa penelitian untuk menganalisa faktor penghambat dan faktor pendukung adopsi $E$ commerce oleh domain Bisnis to Bisnis (B2B) maupun Bisnis to Consumer (B2C) telah dilakukan. Kajian-kajian tersebut telah dilakukan dari kedua perspektif, baik dari perspektif sistem informasi maupun dari perilaku konsumen. Metode penelitian yang digunakan dalam tiap kajian bervairasi. Beberapa kajian menggunakan website assesement tool, sedangkan sebahagian lagi menggunakan metode penelitian sosial.

Almousa (2013) telah melakukan penelitian untuk mengidentifikasi hambatan-hambatan nyata yang mempengaruhi konsumer di Saudi Arabia untuk mengadopsi E-commerce (Almousa, 2013). Penelitian tersebut menggunakan teori dasar Staruss dan Corbin. Almousa menggunakan desain penelitian explorasi untuk mengungkapkan hambatan tangibel yang dihadapi oleh konsumer Saudi saat berbelanja online. Penelitian menemukan bahwa beberapa hambatan serius yang dihadapi oleh konsumer saat berbelanja online adalah lemahnya atau bahkan tidak adanya dukungan layanan setelah pembelian (aftersale support), diikuti oleh faktor tingginya biaya pengangkutan internasional, kemudian adanya kekhawatiran dari konsumer atas tidak sampainya barang. Hal ini menjelaskan bahwa hambatanhambatan tersebut berhubungan dengan pembelanjaan lintas-batas.

Mahmoud dkk. (2006) dalam penelitian nya menjelaskan bahwa organisasi yang memilih untuk menerapkan E-commerce kebanyakan adalah organisasi besar dengan perlengkapan teknologi level menengah hingga level atas. Sebahagian besar organisasi yang merencanakan menggunakan $E$ commerce merupakan organisasi dibidang manufaktur. Ada beberapa alasan enggannya organisasi kecil dan menengah menggunakan $E$ commerce. Diantaranya; produk mereka tidak memiliki karakteristik yang dibutuhkan oleh $E$ commerce, para kompetitor tidak menggunakan $E$ commerce, atau teknologi E-commerce tidak secara langsung memberikan keuntungan finansial. Alasan lainnya meliputi isu keamanan, privasi, sedikitnya sumber daya manusia dengan keahlian yang dibutuhkan, kurangnya sumber daya keuangan dan alasan lainnya yang berhubungan dengan teknologi.
Penelitian yang dilakukan oleh Yasin, juga telah mengidentifikasi beberapa masalah yang harus diperhatikan, yaitu; kebanyakan organisasi setuju bahwa pendekatan secara bertahap lebih cocok untuk digunakan pada perencanaan dan penerapan $E$ commerce. Desain strategi yang baik dan dukungan manajemen sangat penting untuk mencapai keberhasilan dalam implementasi E-commerce.

Penelitian -penelitian terdahulu dapat digunakan sebagai panduan teoritis, untuk melaksanakan penelitian lebih lanjut mengenai tinjauan terhadap penerapan E-commerce pada rumah produksi Seulanga. Keberagaman metodologi dan tool yang digunakan dalam penelitian terkait dengan $E$ commerce, menyediakan peluang bagi peneliti untuk melaksanakan kajian menggunakan tool dan metode yang sesuai dengan tujuan mereka. Berdasarkan beberapa penelitian terkait yang telah dipaparkan sebelumnya, memungkinkan untuk dilakukanya tinjauan dari sisi bisnis atas ketidaksiapan adopsi $E$ commerce. Sehingga penelitian ini akan mengidentifikasi tantangan yang dihadapi oleh rumah produksi Seulanga dalam adopsi E-commerce dari sisi bisnis dengan menggunakan diagram Fishbone.

\section{Metode}

Penelitian ini merupakan penelitian deskriptifkualitatif dengan tujuan utama untuk mengidentifikasi kendala-kendala yang dihadapi oleh rumah produksi Seulanga dalam menerapkan $E$ commerce. Penelitian kualitatif dilaksanakan di gampong Lamteungoh di Kecamatan Peukan Bada, Kabupaten Aceh Besar Provinsi Aceh. Data yang diambil dalam penelitian ini adalah data primer.

Secara garis besar objek penelitian ini terbagi dua yaitu: pengelola rumah produksi Seulanga dan website E-commerce seulangahomemade.com. responden wawancara atau diskusi kelompok adalah seluruh pengelola tetap rumah produksi Seulanga yang berjumlah 10 orang dan berjenis kelamin perempuan. Tim peneliti bertindak sebagai fasilitator dan notulen.

Pengumpulan data dilakukan dengan beberapa cara yaitu; diskusi terpusat kepada pengelola rumah produksi Seulanga dan observasi terhadap website Ecommerce seulangahomemade dengan menggunakan skenario pengujian site search. Aspek dan pertanyaan untuk pengujian site search disajikan pada Tabel 1 . Terlihat bahwa ada empat aspek yang digunakan, dimana masing-masing aspek terdiri dari beberapa pertanyaan uji. 
Tabel 1. Aspek dan pertanyaan pengujian site search

\begin{tabular}{|c|c|c|c|}
\hline Kasus dan Ha & $\begin{array}{l}\text { I uji Coba site search Pada website } \\
\text { seulangahomemade.com }\end{array}$ & con & \\
\hline Aspek & Pertanyaan & Yes & No \\
\hline Kemudahan & apakah search diletakkan di & & \\
\hline Menemukan & tempat yang mudah jumpai user & & \\
\hline Site search & ? & & \\
\hline & apakah diletakkan di bagian & & \\
\hline & $\begin{array}{l}\text { kanan atas website ? } \\
\text { apakah desain search }\end{array}$ & & \\
\hline & $\begin{array}{l}\text { apakah desain search } \\
\text { membuatnya gampang }\end{array}$ & & \\
\hline & ditemukan? & & \\
\hline & $\begin{array}{l}\text { apakah ada kolom untuk teks } \\
\text { pencarian? }\end{array}$ & & \\
\hline Eksekusi Site & apakah user bisa mencari dengan & & \\
\hline search & satu kata, atau dua kata dan & & \\
\hline & mendapatkan hasil yang masuk & & \\
\hline & apakah dapat mencari dengan & & \\
\hline & kode produk? & & \\
\hline & apakah user mendapatkan pesan & & \\
\hline & $\begin{array}{l}\text { validasi bila melakukan inputan } \\
\text { kosong? }\end{array}$ & & \\
\hline Urutan hasil & apakah hasil pencarian & & \\
\hline site search & $\begin{array}{l}\text { ditampilkan dalam urutan yang } \\
\text { masuk akal? }\end{array}$ & & \\
\hline & apakah mungkin untuk & & \\
\hline & melakukan pengururtan ulang & & \\
\hline Tampilan & anakah hasil nencarian mudah & & \\
\hline hasil site & dipahami dan jelas ditampilkan? & & \\
\hline & apakah judul halaman, dan & & \\
\hline & halaman deskripsi ditampilkan? & & \\
\hline & $\begin{array}{l}\text { dtampilkan dalam hasil pencarian } \\
\text { ? }\end{array}$ & & \\
\hline & apakah mudah dipahami dimana & & \\
\hline & untuk mengklik atau melihat & & \\
\hline & produk? & & \\
\hline & apakah ada gambar yang & & \\
\hline & pencarian? & & \\
\hline & apakah ukuran gambar benar? & & \\
\hline & apakah gambar dapat di klik? & & \\
\hline & apakah dengan mengklik pada & & \\
\hline & gambar membawa user ke & & \\
\hline & halaman atau produk yang & & \\
\hline & benar? & & \\
\hline
\end{tabular}

Sebagai data tambahan penelitian juga melakukan observasi terhadap alat-alat pendukung produksi rumah Seulanga.

Analisis data yang digunakan adalah diagram fishbone dengan strategi bauran pemasaran (marketing-mix) atau dikenal juga dengan pendekatan 4P. Fishbone 4P (people, product, price, promotion) merupakan variabel-variabel penting yang dapat menentukan kepuasan dan loyalitas pelanggan (Mohammed dkk., 2015). Analisis fishbone merupakan suatu alat yang digunakan untuk menganalisis masalah dan faktor-faktor yang menyebabkan masalah tersebut (Oktovianisa dkk., 2017). Gambaran diagram fishbone yang digunakan pada penelitian ini diperlihatkan pada Gambar 2.

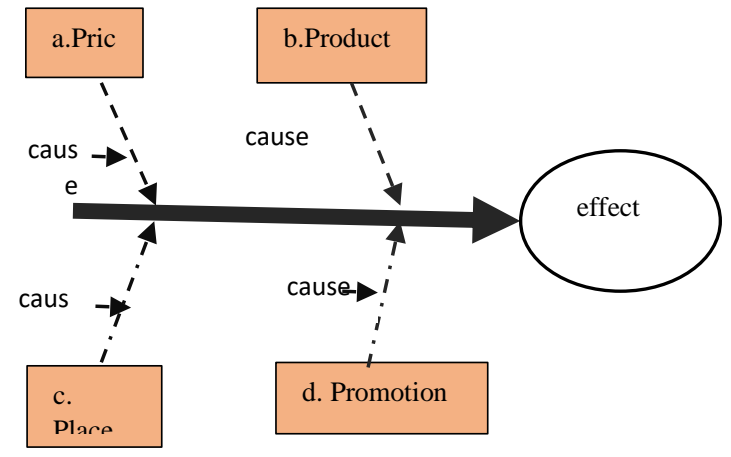

Gambar 2. Diagram fishbone pendekatan 4P

a. Price

Sebab-sebab yang berhubungan dengan pengeluaran uang, waktu serta usaha yang dikeluarkan oleh pelanggan dalam membeli produk dan layanan yang diberikan oleh perusahaan.

b. Product

Merupakan semua komponen dari kinerja layanan yang menciptakan nilai bagi pelanggan, memberikan manfaat, memenuhi kebutuhan, dan dapat memuaskan konsumen.

c. Place

Tempat dalam marketing mix biasa disebut dengan saluran distribusi, saluran dimana produk tersebut sampai kepada konsumen. Saluran distribusi adalah, Saluran yang digunakan oleh produsen untuk menyalurkan produk tersebut dari produsen sampai ke konsumen atau industri pemakai (Mohammed dan Hilda, 2015). Fasilitas distribusi dan lokasi merupakan faktor penting dalam memenuhi penawaran-permintaan dari konsumen.

d. Promotion

Merupakan semua aktivitas komunikasi dan perancangan intensif untuk membangun persepsi pelanggan yang dikehendaki perusahaan atas layanan spesifik yang perusahaan berikan (Oktovianisa dkk., 2017).

\section{Hasil dan Pembahasan}

Rumah produksi Seulanga merupakan usaha berbasis masyarakat yang dijalankan oleh 10 orang anggota tetap. Para anggota yang berasal dari desa Lamteungoh tersebut memiliki keahlian yang seragam. Semuanya ikut dalam proses produksi. Seluruh anggota tetap Seulanga adalah ibu rumah tangga dengan literasi informasi dan teknologi komputer yang rendah. Penelitian ini telah berhasil melakukan diskusi kelompok terpusat kepada anggota rumah produksi Seulanga. Diskusi tersebut dimaksudkan untuk memberikan gambaran mengenai proses bisnis yang telah dijalankan oleh rumah produksi seulanga. Rekapitulasi pertanyaan penelitian beserta jawaban yang diberikan oleh anggota rumah produksi Seulanga ditampilkan pada Tabel 2. 
Tabel 2. Rekapitulasi Hasil Diskusi

\begin{tabular}{|c|c|c|}
\hline Pertanyaan & Jawaban & Keterangan \\
\hline $\begin{array}{l}\text { 1. Harga bakso atau } \\
\text { nugget? }\end{array}$ & $\begin{array}{l}\text { harga bakso ikan } 15 \text { ribu } \\
\text { seperempat } \\
\text { tapi kalo untuk bakso udang } \\
\text { harganya Rp. } 75.000 \text { sekilo } \\
\text { harga bakso dan nugget } \\
\text { disesuaikan dengan bahan baku }\end{array}$ & ++ \\
\hline $\begin{array}{l}\text { 2.Bahan baku bakso } \\
\text { atau nugget apa saja? }\end{array}$ & $\begin{array}{l}\text { macam-macam, tergantung } \\
\text { yang ada, kalau lagi susah } \\
\text { melaut, atau harga ikan mahal } \\
\text { maka bisa buat bakso atau } \\
\text { nugget dari ayam, atau dari } \\
\text { sayur, tergantung pesanan }\end{array}$ & ++ \\
\hline 3.Cara memasarkan & Menggunakan BBM, WA & \\
\hline bakso atau nugget? & Promosi mulut ke mulut & ++ \\
\hline $\begin{array}{l}\text { 4.Cara bakso atau } \\
\text { nugget sampai ke } \\
\text { pelanggan? }\end{array}$ & $\begin{array}{l}\text { di jemput ke tempat produksi } \\
\text { oleh pelanggan, karena kami } \\
\text { biasanya buat bakso atau nugget } \\
\text { kalau ada pesanan }\end{array}$ & ++ \\
\hline & $\begin{array}{l}\text { Diantar oleh anak atau anggota } \\
\text { rumah produksi seulanga yang } \\
\text { ada waktu } \\
\text { Diantar oleh paket kiriman, ada } \\
\text { langganan kami yang berada di } \\
\text { lhoksemawe, pelanggan kami } \\
\text { perorangan saja }\end{array}$ & \\
\hline & Di titip ke toko langganan & \\
\hline $\begin{array}{l}\text { 5.Apa kendala untuk } \\
\text { memproduksi bakso } \\
\text { atau nugget? }\end{array}$ & $\begin{array}{l}\text { Kadang bahan utama mahal } \\
\text { seperti ikan } \\
\text { Mesin pembeku tidak ada }\end{array}$ & $\begin{array}{c}++ \\
++\end{array}$ \\
\hline $\begin{array}{l}\text { 6.Analisis biaya dan } \\
\text { keuntungan produksi } \\
\text { bagaimana? }\end{array}$ & $\begin{array}{l}\text { Selama ini harga ditetapkan } \\
\text { sesuai umumnya harga nugget } \\
\text { dan bakso di pasaran } \\
\text { Belum dilakukan }\end{array}$ & ++ \\
\hline
\end{tabular}

Keterangan :

++ : dijawab oleh lebih dari satu responden

* : kesimpulan yang ditarik oleh peneliti

Untuk setiap jawaban yang disetujui atau dibenarkan oleh beberapa orang anggota diskusi kelompok diberikan kode ++. Sebagai contoh untuk nomor pertanyaan 1 , lebih dari satu orang responden menjawab bahwa harga bakso ikan adalah 15 ribu untuk tiap $1 / 4$ kilogramnya. Untuk pertanyaan nomor 6 mengenai analisis biaya dan keuntungan produksi pada Tabel.2, berdasarkan jawaban anggota, peneliti menyimpulkan bahwa belum dilakukan analisis biaya, dan diberikan kode *. Rekapitulasi data Tabel 2 selanjutnya digunakan sebagai dasar membuat analisis diagram fishbone dengan pendekatan 4P (Price, Product, Place, Promotion) Gambar 3. Merupakan Diagram Fishbone dengan pendekatan 4P, dimana pada bagian kepala berisi permasalahan utama yang menjadi latar belakang dilakukannya penelitian ini.

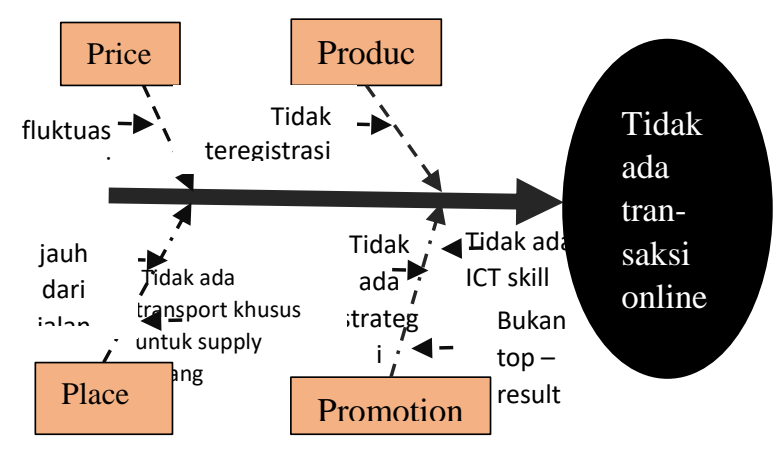

Gambar 3. Diagram Fishbone

Harga yang fluktuatif, harga produk cenderung bervariasi tergantung ketersediaan bahan baku ikan. Saat cuaca baik dan panen ikan melimpah maka harga produk bakso dan nugget menjadi murah begitu pula sebaliknya. Meski Seulanga telah memiliki peralatan Storage yang memadai, yang merupakan hibah dari Universitas Syiah Kuala, namun karena tidak ada nya prediksi yang tepat oleh tim produksi berkaitan dengan ketersediaan bahan baku ikan, tetap saja terkadang pesanan tidak bisa diproses, saat musim pancaroba terjadi. Merupakan tantangan bagi rumah produksi Seulanga untuk mengatasi masalah tersebut, dan mampu menetapkan harga dasar yang lebih murah dari produk sejenis. Berdasarkan data pada Tabel 2. Pertanyaan 6, selama ini tidak dilakukan analisis biaya dan keuntungan. Penetapan harga mengikuti harga produk sejenis. Harga yang fluktuatif merupakan hambatan untuk pemasaran E-commerce.

Untuk produk, kendala yang dihadapi adalah belum teregistrasinya produk. Meskipun Seulanga sudah beroperasi lebih dari delapan tahun, tapi produk mereka belum teregistrasi di balai makanan dan obat, atau dinas kesehatan. Seulanga memproduksi dua jenis makanan olahan ikan , yaitu; nugget ikan dan bakso ikan yang dibuat dengan bumbu alami. Gambar 4. Menampilkan kemasan produk rumah Seulanga yang sangat sederhana dan apa adanya.

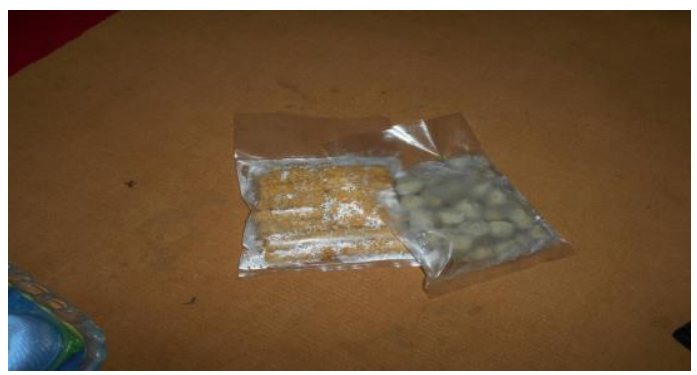

Gambar 4. Produk Bakso dan Nugget

Produk ini sehat dan aman dikonsumsi oleh anakanak dan keluarga karena tidak mengandung pengawet dan penguat rasa buatan. Namun sangat 
sulit menyakinkan konsumer online, karena produk Seulaga belum memiliki label sehat dari dinas terkait. Ditambah lagi makanan basah termasuk produk yang jarang dibeli secara online. Berdasarkan data statistik dari kementrian informasi dan komunikasi produk yang paling banyak dibeli secara online adalah katagori fashion dan aksesoris, seperti terlihat pada gambar 5, ditahun 2015 katagori tersebut mencapai $37,6 \%$ pembelian. Kenyataan ini menjadi tantangan untuk Seulanga, agar segera melabelkan produk mereka dan membangun keunikannya, sehingga pembeli akan mencari produk Seulanga.

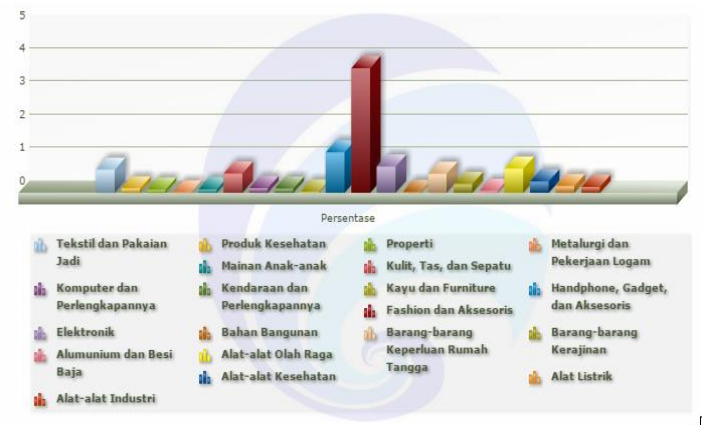

Gambar 5. Katagori produk berdasarkan jumlah pembelian untuk tahun 2015

Hasil observasi terhadap alat-alat pendukung produksi yang cenderung masih tradisional disajikan pada Gambar 6 dan Gambar 7. Dari Gambar terlihat bahwa untuk perebusan dan pencetakan nugget, rumah produksi Seulanga masih menggunakan alatalat yang sederhana dan berkapasitas rendah. Hal tersebut juga menjadi tantangan sendiri bagi Seulanga dalam mengadopsi E-commerce. Mengingat bahwa jangkauan pemasaran E-commerce yang sangat luas, diperlukan kesiapan dari rumah produksi Seulanga untuk mampu memproduksi produk dalam skala besar, disaat tingginya permintaan. Dengan peralatan yang ada saat ini, Seulanga dipastikan tidak siap untuk mengadopsi $E$ commerce.
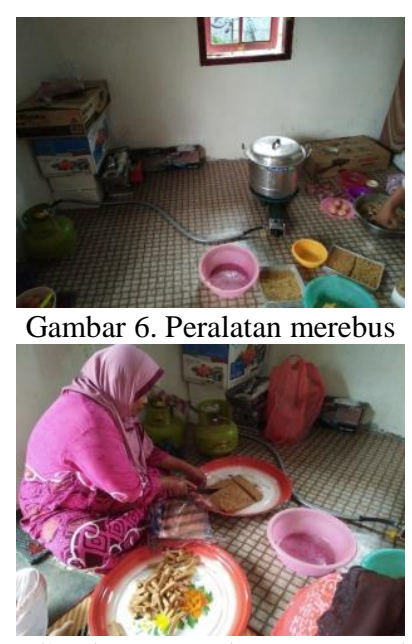

Gambar 7. Peralatan mencetak
Pada bagian saluran distribusi, secara permanen belum tersedianya angkutan khusus baik itu sepeda motor atau kendaraan roda empat yang diperuntukkan sebagai media transportasi persediaan barang. Selama ini, anggota seulanga mengantarkan produk pesanan dengan menggunakan kendaraaan pribadi. Namun sering juga pelanggan yang datang untuk mengambil pesanan. Lokasi rumah produksi terbilang jauh dari jalan utama. Seperti terlihat pada gambar 8 .

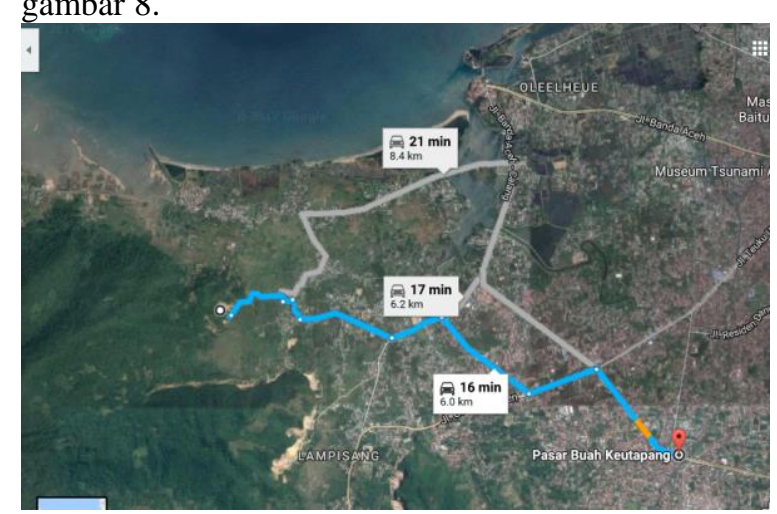

Gambar 8. Lokasi rumah produksi seulanga dari pasar tradisional terdekat

Meski demikian, produk selalu sampai ketangan konsumen tepat waktu, hal ini karena pengelola seulanga telah memiliki beberapa toko tetap tempat penitipan produk yang lebih dekat dengan jalan utama dan mudah diakses pelanggan.

Pada bagian promosi. Kurangnya strategi promosi juga menjadi faktor yang berpengaruh terhadap tidak adanya transaksi online yang terjadi. Rumah produksi seulanga tidak memiliki strategi promosi serta tidak menerapkan Search Engine Optimation (SEO) untuk websitenya. Terbukti saat keyword bakso dan nugget dimasukkan ke mesin pencari google, seulangahomemade.com tidak muncul pada halaman hasil pencarian. Hasil pencarian website seulangahomemade.com dengan mesin pencari google.com disajikan padaa gambar 9. Seulanga juga tidak menjual produknya di website E-commerce terkenal seperti tokopedia.com.

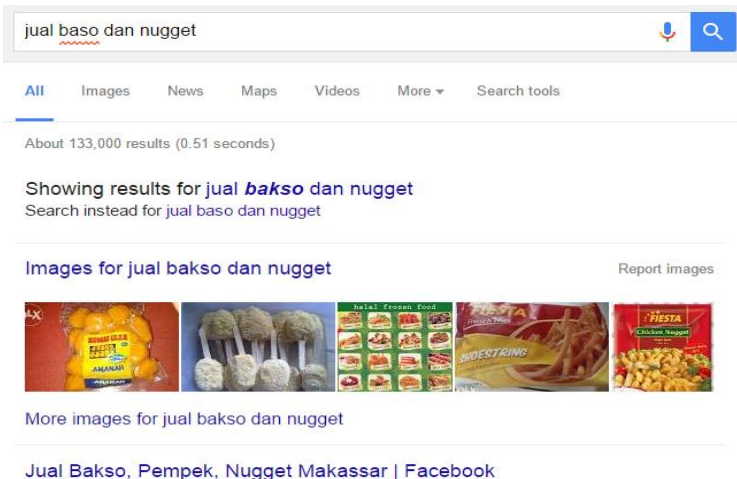

Jual Bakso, Pempek, Nugget Makassar | Facebook

Gambar. 9 Hasil pencarian untuk nugget dan bakso diakses pada juni 2017 
Pengecekan SEO score juga dilakukan pada juni 2017 di situs chkme.com, yang merupakan situs gratis untuk pengecekan score SEO. Hasil menunjukan bahwa score SEO untuk website seulangahomemade.com mencapai $85 \%$, ini termasuk baik. Pemeriksaan score SEO dilakukan secara online dan disajikan pada Gambar 10.

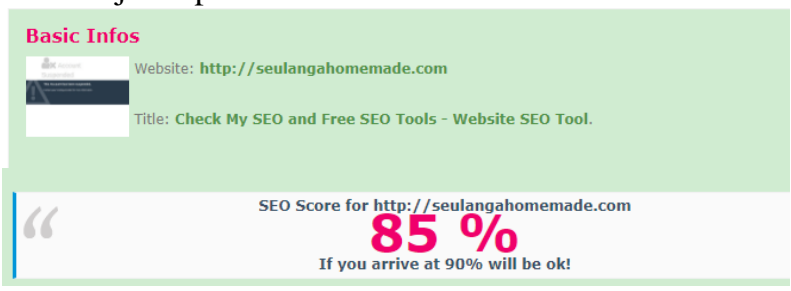

Gambar. 10 Hasil SEO score

Dari sisi tenaga kerja, juga merupakan tantangan. Karena tidak ada pembagian tugas yang pasti antar anggota. Anggota yang bertanggung jawab terhadap produksi juga bertanggung jawab pada promosi mulut ke mulut. Tambahan lagi pemasaran dan penjualan online belum secara serius dikembangkan. Tidak ada alokasi dana untuk pemasaran. Meski website E-commerce telah di hosting namun pengelolaan nya masih sederhana. Gambar 11 menyajikan website E-commerce seulangahomemade.com yang telah dimiliki oleh rumah produksi Seulanga.

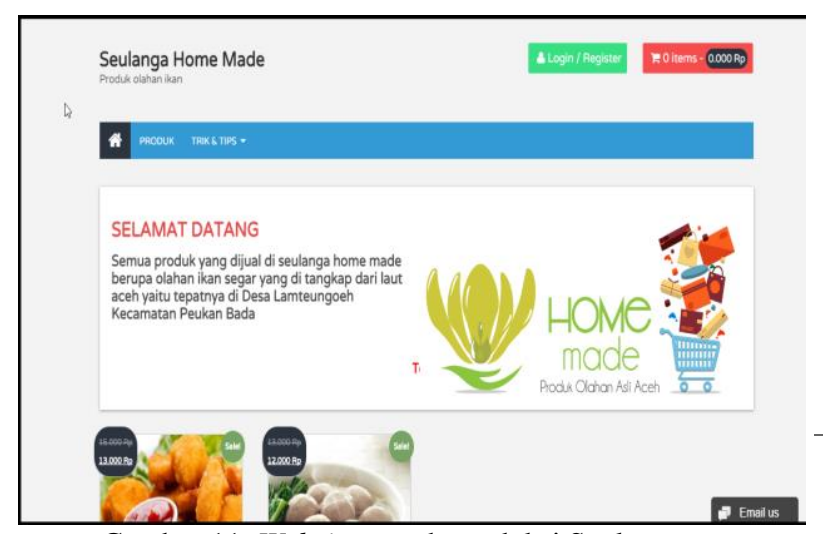

Gambar 11. Website rumah produksi Seulanga

Website tersebut telah memiliki beberapa fitur bagus seperti: kolom pencarian, katagori, zoom produk, informasi pembayaran dan pengiriman, login pelanggan dan pendaftaran,video tutorial, lokasi, privasi policies dan sosial media. Secara keseluruhan desain dan layout website tersebut baik, 9 dari sepuluh responden menyatakan desain dan layout website seulangahomemade.com sudah baik.

Namun site search pada website seulangahomemade.com tidak meletakkan dibagian kanan atas seperti terlihat dari Tabel 3. Untuk butir pertanyaan kedua dari aspek kemudahan menemukan site search.
Tabel 3. Rekapitulasi Site Search Test

\begin{tabular}{|c|c|c|c|}
\hline \multicolumn{4}{|c|}{$\begin{array}{c}\text { Kasus dan Hasil uji Coba site search Pada website e-commerce } \\
\text { seulangahomemade.com }\end{array}$} \\
\hline Aspek & Pertanyaan & Yes & No \\
\hline \multirow{6}{*}{$\begin{array}{l}\text { Kemudahan } \\
\text { Menemukan } \\
\text { Site search }\end{array}$} & apakah search diletakkan di & $\mathrm{v}$ & \\
\hline & tempat yang mudah jumpai & & \\
\hline & user? & & \\
\hline & $\begin{array}{l}\text { apakah diletakkan di bagian } \\
\text { kanan atas website? }\end{array}$ & & $\mathrm{V}$ \\
\hline & $\begin{array}{l}\text { apakah desain search } \\
\text { membuatnya gampang } \\
\text { ditemukan? }\end{array}$ & $\mathrm{v}$ & \\
\hline & $\begin{array}{l}\text { apakah ada kolom untuk teks } \\
\text { pencarian? }\end{array}$ & $\mathrm{v}$ & \\
\hline \multirow[t]{3}{*}{$\begin{array}{l}\text { Eksekusi Site } \\
\text { search }\end{array}$} & $\begin{array}{l}\text { apakah } \text { user bisa mencari } \\
\text { dengan satu kata, atau dua kata } \\
\text { dan mendapatkan hasil yang } \\
\text { masuk akal? }\end{array}$ & $\mathrm{V}$ & \\
\hline & $\begin{array}{l}\text { apakah dapat mencari dengan } \\
\text { kode produk? }\end{array}$ & $\mathrm{V}$ & \\
\hline & $\begin{array}{l}\text { apakah } \text { user mendapatkan pesan } \\
\text { validasi bila melakukan inputan } \\
\text { kosong? }\end{array}$ & & $\mathrm{V}$ \\
\hline \multirow[t]{2}{*}{$\begin{array}{l}\text { Urutan hasil } \\
\text { site search }\end{array}$} & $\begin{array}{l}\text { apakah hasil pencarian } \\
\text { ditampilkan dalam urutan yang } \\
\text { masuk akal? }\end{array}$ & $\mathrm{v}$ & \\
\hline & $\begin{array}{l}\text { apakah mungkin untuk } \\
\text { melakukan pengururtan ulang } \\
\text { terhadap hasil pencarian? }\end{array}$ & & $\mathrm{V}$ \\
\hline \multirow{9}{*}{$\begin{array}{l}\text { Tampilan } \\
\text { hasil site } \\
\text { search }\end{array}$} & apakah hasil pencarian mudah & $\mathrm{V}$ & \\
\hline & dipahami dan jelas ditampilkan? & & \\
\hline & $\begin{array}{l}\text { apakah judul halaman, dan } \\
\text { halaman deskripsi ditampilkan? }\end{array}$ & $\mathrm{V}$ & \\
\hline & $\begin{array}{l}\text { apakah ada image yang } \\
\text { dtampilkan dalam hasil } \\
\text { pencarian? }\end{array}$ & $\mathrm{v}$ & \\
\hline & $\begin{array}{l}\text { apakah mudah dipahami dimana } \\
\text { untuk mengklik atau melihat } \\
\text { produk? }\end{array}$ & $\mathrm{v}$ & \\
\hline & $\begin{array}{l}\text { apakah ada gambar yang } \\
\text { dikembalikan dari hasil } \\
\text { pencarian? }\end{array}$ & $\mathrm{v}$ & \\
\hline & apakah ukuran gambar benar? & $\mathrm{v}$ & \\
\hline & apakah gambar dapat di klik? & $\mathrm{v}$ & \\
\hline & $\begin{array}{l}\text { apakah dengan mengklik pada } \\
\text { gambar membawa } \text { user ke } \\
\text { halaman atau produk yang } \\
\text { benar? }\end{array}$ & $\mathrm{v}$ & \\
\hline
\end{tabular}

Untuk kolom pencarian masih terdapat ada beberapa fasilitas pencarian yang harus dikembangkan oleh pengembang web seulanga, diantaranya; meletakkan kolom pencarian dibagian kanan atas halaman web atau dibagian tengah, seperti yang umum dilakukan oleh halaman-halaman website lain. Hal tersebut akan mempermudah pengguna untuk menemukan kolom pencarian, karena selama ini kolom pencarian diletakkan di halaman web, sejajar dengan informasi bantuan dan kontak. Gambar 11 memperlihatkan screen shot untuk kolom pencarian yang diletakkan dibagian footer webiste. 


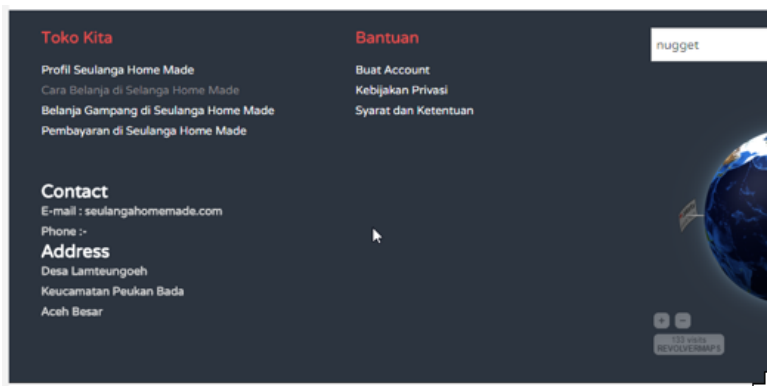

Gambar 11. Halaman informasi

Hasil pengujian terhadap Site Search pada website E-commerce seulangahome menunjukan bahwa satu dari empat kriteria aspek eksekusi site search tidak dipenuhi oleh website seulanga. Saat pengguna tidak memasukan data ( kolom pencarian masih kosong) lalu tombol pencarian diklik, pengguna tidak mendapatkan validasi apapun. Dalam perancangan site search sebaiknya pencarian kosong atau inputan tidak lengkap medapatkan umpan balik dari website. Rincian aspek, pertanyaan dan jawaban dapat dilihat pada Tabel 3 diatas.

Kurangnya tenaga kerja yang terampil dalam bidang manajerial dan dalam bidang IT membuat rumah produksi Seulanga kesulitan untuk melakukan promosi online. Permasalahan lain yang dijumpai adalah produk yang belum terdaftar di badan Resmi Pangan membuat rumah produksi Seulanga membutuhkan interfensi dari luar untuk mempertahankan keberlangsungan bisnis mereka.

\section{Kesimpulan}

Identifikasi hambatan-hambatan dalam adopsi $E$ commerce oleh Rumah produksi Seulanga telah dilakukan menggunakan analisis Fishbone pendekatan 4P dengan teknik pengumpulan data berupa diskusi terpusat dan pengujian site search. Faktor-faktor hambatan yang berhasil diidentifikasi yaitu; produk belum teregistrasi, harga yang berfluktuasi, tidak ada staff yang terampil dalam manajemen dan Teknologi Informasi, tidak adanya strategi promosi tertentu serta fitur site search yang masih belum bisa memenuhi seluruh kriteria pencarian yang handal.

Keunggulan dari penelitian ini adalah adanya kombinasi metode analisa yang dilakukan pada saat penelitian. Hambatan adopsi E-commerce tidak saja dilihat dari sisi kesiapan Website E-commerce tapi juga dilakukan analisa dari aspek organisasi, sehingga penelitian ini sampai pada kesimpulan bahwa rumah produksi seulanga belum siap untuk melakukan adopsi E-commerce dalam bisnis mereka. Organisasi ini membutuhkan interfensi dari pihak luar untuk meningkatkan bisnis mereka.

\section{Ucapan Terimakasih}

Terimakasih kepada Dikti dan Universitas Syiah Kuala yang telah mendanai penelitian ini, dalam program IbM: ipteks bagi Masyarakat dana DP2M tahun 2016.

\section{Daftar Pustaka}

Almousa, M., 2013. Barriers to E-commerce Adoption : Consumer's perpective from a developing country. Journal of Ibusiness 2013(5), 65-71.

Batey, T., 2013. How to test a site search. http:testing-web-sites.co.uk/2013/01/29/how-totest-a-site- search/ diakses tanggal 01 Oktober 2017.

Bazier, B., 1995. Black-box testing : techniques for functional Testing of Sofware and Systems, John wiley \& Sons,Inc. New York

Bose, T.K., 2012. Application of Fishbone Analysis for Evaluating Supply Chain and Business Process A Case Study On The St James Hospital. International Journal of Managing Value and Supply Chains (IJMVSC) 3 (1), 17-24.

Chen, J., Mcqueen R.J, 2008. Factors Affecting ECommerce Stage of Growth in Small Chinese Firm in New Zeland: An Analysis of Adoption Motivators and Inhibitors. Journal of Global Information Mangement, 16(1), 26-61.

Editor, 2017. 8 important Segments of testing eCommerce websites.Website: http:// softwaretestinghelp.com/ecommercetesting/ diakses tanggal 5 October 2017.

Mahmoud, M.Y., Czuchry, J.A., 2006. E-commerce implementation challenges: Small to mediumsized versus large organisations Article in International Journal of Business Information Systems 1 (3). 256-275

Mohammed,T.N., Hilda, M., 2015. 4Ps: A Strategy to Secure Customers' Loyalty via Customer Satisfaction. International Journal of Marketing Studies 7(4), 78-87.

Nursanty,R., Fahlevi,H., Juwita., 2015. (IbM) Pemberdayaan Ekonomi Masyarakat Melalui Usaha Olahan Ikan di Gampong Lamteungoh dan Lam Isek Kecamatan.

Oktovianisa, P.R., Wibawa, B.M., Titah, L., 2017. Identifikasi Permasalahan Komplain pada ECommerce Menggunakan metode Fishbone. Jurnal Sains dan Seni ITS 6(1), D37-D41.

Pokja AMPL Aceh Besar, 2011. Buku Putih Sanitasi Kabupaten Aceh Besar. Pemerintah Daerah Aceh Besar. Peukan Bada Aceh Besar, Laporan Pengabdian, Universitas Syiah Kuala.

Poerwanto, G., 2016. Diagram Fishbone. Website: sites.google.com/site/kelolakualitas/Diagramfishbonel. diakses tanggal 12 November 2016. 
Siregar, R.R., 2010. Strategi Meningkatkan Persaingan Bisnis Perusahaan dengan Penerapan E-Commerce. http://blog.trisakti.ac.id/ diakses tanggal 12November 2016.

Vermaat., 2007. Elektronik E-commerce. ANDI. Yogyakarta.
Wikipedia, 2017. Test Plan. https://en.wikipedia.org/ wiki/ Test_plan. diakses tanggal 01 Oktober 2017. 